\title{
Lypsylehmien sorkkasairauksien perinnölliset tunnusluvut
}

\author{
Minna Laakso ${ }^{1)}$, Minna Kujala ${ }^{2)}$ ja Matti Ojala ${ }^{1)}$ \\ ${ }^{1)}$ Helsingin yliopisto, Kotieläintieteen laitos, PL 28, 00014 Helsingin yliopisto, \\ etunimi.sukunimi@helsinki.fi \\ ${ }^{2)}$ Helsingin yliopisto, Kliinisen eläinlääketieteen laitos, Saaren yksikkö, Pohjoinen pikatie 800, 04920 \\ Saarentaus, minna.j.kujala@helsinki.fi
}

\section{Tiivistelmä}

Sorkkasairaudet heikentävät lypsylehmien hyvinvointia. Vakavat sorkkaviat johtavat usein lehmän ennenaikaiseen poistamiseen ja aiheuttavat taloudellisia tappioita lypsykarjatiloilla.

Tämän tutkimuksen tavoitteena oli määrittää eri sorkkasairauksien periytymisasteen arvioita sekä tutkia muita sorkkasairauksiin vaikuttavia tekijöitä.

Tutkimusaineistona käytettiin Terveet Sorkat ${ }^{\mathrm{TM}}$-ohjelman havaintoja lypsylehmien sorkkaterveydestä. Terveet Sorkat -ohjelma on Suomen Sorkkahoitajien Yhdistyksen, Suomen Rehun ja Vetman Oy:n valtakunnallinen ohjelma. Aineistossa on arvioitu joko-tai- eli 0/1 -asteikolla seuraavat sorkkasairaudet: vertymiä anturassa, krooninen sorkkakuume, valkoviivan repeämä, anturahaavauma, sorkkavälin ihotulehdus, kantasyöpymä, sorkka-alueen ihotulehdus, sorkkakiertymä ja muu sorkkasairaus. Muihin sorkkasairauksiin luokitellaan esimerkiksi vierasesineet, sorkkaluun murtumat ja muut viat, joille ei ole erillistä koodia. Sairaudet olivat 43 sorkkahoitajan arvioimia.

Lopullisessa aineistossa oli 74410 havaintoa 41087 lypsylehmältä ja hieholta. Lopullisen aineiston eläimet olivat 1462 tilalta. Roduittain aineisto jakaantui seuraavasti: ayrshire 29 159, holsteinfriisiläinen 11637 ja suomenkarja 291 yksilöä. Aineiston eläimet olivat syntyneet vuosina 1987-2004. Aineiston eläimet olivat 2381 sonnin jälkeläisiä.

Aineiston esikäsittelyyn, alustaviin tilastollisiin analyyseihin ja kiinteiden tekijöiden merkitsevyyden testaamiseen F-testillä käytettiin WSYS-ohjelmistoa. Lisäksi kiinteiden tekijöiden tilastollista merkitsevyyttä testattiin logit-mallilla SAS-ohjelmistolla. Sorkkasairauksien periytymisasteiden arviointiin tarvittavat varianssikomponentit laskettiin Restricted Maximum Likelihood (REML)menetelmällä käyttäen VCE4-ohjelmistoa.

Eläimistä 54,2 prosenttia oli terveitä eli yksi tai useampi sorkkasairaus oli 45,8 prosentilla eläimistä. Vertymiä anturassa oli 28,2 , kroonista sorkkakuumetta 1,7 , valkoviivan repeämää 10,6 , anturahaavaumaa 3,5 , sorkkavälin ihotulehdusta 0,9 , kantasyöpymää 8,1 , sorkka-alueen ihotulehdusta 0,2 , sorkkakiertymää 9,2 ja muita sorkkasairauksia 0,8 prosentilla havainnoista.

Suomenkarjan sorkkaterveys oli muita rotuja parempi, mutta suomenkarjan eläimiä oli tutkimuksessa vain vähän. Ayrshire-rotuisten eläinten sorkkaterveys oli sorkkakiertymää lukuun ottamatta holstein-friisiläis -rotuisia eläimiä parempi. Navettatyyppi oli tilastollisesti erittäin merkitsevä selittäjä jokaisen sorkkasairauden kohdalla. Erot navettatyyppien välillä olivat selkeitä ja kaikkia sorkkasairauksia esiintyi vähiten parsinavetoissa.

Kova, kuivittamaton makuualusta lisäsi sorkkasairausriskiä. Poikimakerran ja vuodenajan vaikutus oli erilainen eri sorkkasairauksiin. Sorkkasairauksia esiintyi yleisesti ottaen enemmän alkulypsykaudella (60-180 päivää poikimisesta) ja korkeatuottoisimmilla eläimillä, mutta näin ei ollut kaikkien sorkkasairauksien kohdalla.

Kaikille sorkkasairauksille saadut periytymisasteiden arviot olivat alhaisia. Alhaisin periytymisasteen arvio saatiin kantasyöpymälle $(0,02)$, joka on tartunnallinen sorkkasairaus ja korkein periytymisasteen arvio saatiin sorkkasairauksille yhtenä ominaisuutena $(0,06-0,07)$.

Tutkimuksen perusteella perimän osuus 0/1-asteikolla arvioituihin sorkkasairauksiin ei ole kovin suuri. Sorkkasairauksien ennaltaehkäisyssä tulisi kiinnittää erityistä huomiota navetan olosuhteisiin, säännölliseen sorkkahoitoon ja oikeaan ruokintaan.

Asiasanat: lypsykarja, sorkkaterveys, periytymisaste, sorkkahoito 


\section{Johdanto}

Kuluttajat ovat yhä kiinnostuneempia tuotantoeläinten hyvinvoinnista ja myös tuottajat haluavat panostaa eläintensä hyvinvoinnin parantamiseen. Terve eläin on taloudellinen ja myös miellyttävä työskentelykumppani. Vakavat sorkkaviat johtavat hyvin usein lehmän ennenaikaiseen poistamiseen. Pihattonavetoiden ja automaattisten lypsyjärjestelmien yleistyessä lehmien liikuntakyvyn merkitys kasvaa, sillä jos lehmä ei kykene siirtymään riittävän säännöllisesti syömään ja lypsylle se joudutaan poistamaan. Sorkka- ja jalkaviat aiheuttavat ennenaikaisten poistojen ja heikentyneen hyvinvoinnin lisäksi taloudellisia tappioita, jotka aiheutuvat alentuneesta maitotuotoksesta ja kasvaneista eläinlääkintä- ja sorkkahoitokuluista sekä työmenekistä. Lisäksi sorkkasairaudet aiheuttavat hedelmällisyysongelmia ja ovat mahdollisesti yhteydessä korkeaan solulukuun (Manske 2002). Sorkkiaan aristava lehmä on myös altis vedinvaurioille.

Sorkkaviat ovat suhteellisen yleisiä lypsykarjatiloilla. Ruotsalaisessa tutkimuksessa (Manske 2002) 72 prosentilla 4899 lehmästä havaittiin ainakin yksi sorkkavika. Terveet Sorkat ${ }^{\mathrm{TM}}$-ohjelman vuonna 2002 hoidetuista 29038 lehmästä 48,7 prosentilla oli yksi tai useampi sorkkasairaus (Kujala ym. 2004).

Sorkkasairauksien periytyvyydestä on vain vähän tutkimuksia, koska aineistoa sorkkaterveydestä on hankala ja kallis kerätä (Huang ja Shanks 1995). Tutkimuksissa sorkkasairauksien periytymisasteen arviot ovat yleensä vaihdelleet nollasta keskinkertaiseen (mm. Huang ja Shanks 1995, Nielsen ym. 2000, Zwald ym. 2004, Koenig ym. 2005 ja van der Waaij ym. 2005). Suomessa tutkimusta sorkkasairauksien periytyvyydestä ei ole aiemmin tehty.

Tämän tutkimuksen tavoitteina oli määrittää eri sorkkasairauksien periytymisasteen arvioita sekä tutkia muita sorkkasairauksiin vaikuttavia tekijöitä.

\section{Aineisto ja menetelmät}

Aineistona tutkimuksessa käytettiin Terveet Sorkat -ohjelman havaintoja lypsylehmien sorkkaterveydestä. Terveet Sorkat -ohjelma on Suomen Sorkkahoitajien Yhdistyksen, Suomen Rehun ja Vetman Oy:n valtakunnallinen ohjelma sorkkaterveyden kohentamiseksi ja sorkkasairauksien ennaltaehkäisemiseksi (Jankko 2002). Terveet Sorkat -ohjelmaan liittyminen on vapaaehtoista.

Terveet Sorkat -ohjelman tietoja sorkkaterveydestä ei ole kerätty kotieläinjalostustutkimusta varten, vaan tilatason ja myös valtakunnan tason sorkkaterveystilanteen seurantaan. Aineisto on kuitenkin ainoa koko Suomen alueelta kerätty aineisto sorkkasairauksista. Sorkkaterveysaineisto tallennettiin Microsoft Excel -taulukkolaskentaohjelmalla sorkkahoitajien vuosina 2003 ja 2004 täyttämistä kaavakkeista. Alkuperäisessä aineistossa oli 84946 havaintoa. Merkintöjä oli tehnyt 44 sorkkahoitajaa, joista 36 oli käynyt Terveet Sorkat -koulutuksen.

Aineistossa on luokiteltu joko-tai- eli 0/1 -asteikolla seuraavat sorkkasairaudet: vertymiä anturassa, krooninen sorkkakuume, valkoviivan repeämä, anturahaavauma, sorkkavälin ihotulehdus, kantasyöpymä, sorkka-alueen ihotulehdus, sorkkakiertymä ja muu sorkkasairaus. Muihin sorkkasairauksiin luokitellaan esimerkiksi vierasesineet, sorkkaluun murtumat ja muut viat, joille ei ole erillistä koodia. Terveen eläimen sorkkahoito merkitään ennaltaehkäisevänä hoitona.

Sorkkasairaushavaintojen lisäksi Terveet Sorkat -ohjelmasta saatiin tiedot navettatyypistä, makuualustasta, lantakäytävistä, lantalatyypistä ja hoitokerroista vuodessa. Lisäksi jokaisella hoitokerralla oli merkitty tilan käyttämä ruokintatyyppi ja lypsylehmien lukumäärä tilalla kyseisenä sorkkahoitopäivänä. Aineistosta poistettiin virheelliset havainnot eli eläimet, jotka oli merkitty virheellisesti sekä terveiksi että sairaiksi ja eläimet, joilta puuttui tieto sorkkaterveydestä. Sorkkaterveysaineistossa eläinten tunnistetietoina olivat maaseutukeskus-karja-korvanumerot, mutta osalta lehmistä oli tallennettu vain nimi. Sorkkaterveysaineisto yhdistettiin ProAgria Maatalouden laskentakeskuksen tuotosseurantaaineistoon. Tässä vaiheessa poistettiin havainnot eläimistä, joille ei löytynyt maaseutukeskus-karjakorvanumeroa vastaavaa syntymätunnusta. Tuotosseuranta-aineistosta saatiin analyyseihin mukaan lehmien polveutumiset, rotu ja ikä sekä poikima- ja tuotostiedot. Havainnot lehmistä, joiden isä oli tuntematon poistettiin.

Lopullisessa aineistossa oli 74410 havaintoa 41087 lypsylehmältä ja hieholta. Suomessa oli vuoden 2003 lopussa lypsylehmiä 330000 (Maa- ja metsätaloustuottajien Keskusliitto 2004), joten tutkimusaineiston eläinmäärä on yli 10 prosenttia Suomen lypsylehmäpopulaatiosta. Tuotosseurantaan vuonna 2004 kuuluneista 248810 lypsylehmästä (Lohenoja 2005) aineiston eläinmäärä oli lähes 30 prosenttia. Lopullisen aineiston eläimet olivat 1462 tilalta ja havainnot olivat 43 sorkkahoitajan ke- 
räämiä. Havaintojen lukumäärä sorkkahoitajaa kohti vaihteli 25-7 077. Aineiston eläimet olivat syntyneet vuosina 1987-2004. Aineiston eläimet olivat 2381 sonnin jälkeläisiä. Jälkeläisten lukumäärä vaihteli 1-949 jälkeläistä/isä. Alle 10 jälkeläistä oli 1542 sonnilla.

Aineiston esikäsittelyyn, alustaviin analyyseihin ja kiinteiden tekijöiden tilastollisen merkitsevyyden testaamiseen F-testillä käytettiin WSYS-L- ja XWSYS-ohjelmistoja (Vilva 1998). Lisäksi kiinteiden tekijöiden tilastollista merkitsevyyttä testattiin logit-mallilla SAS-ohjelmistolla. Sorkkasairauksien periytymisasteiden arviointiin tarvittavat varianssikomponentit laskettiin Restricted Maximum Likelihood (REML)-menetelmällä käyttäen VCE4-ohjelmistoa (Groeneveld 1997).

Kiinteiden tekijöiden merkitsevyyttä tutkittiin kiinteiden tekijöiden mallilla:

$\mathrm{Y}_{i j k l m n o p q r s t u}=\mu+$ rotu $_{i=1 . .3}+$ poikimakerta $_{j=1 . .8}+$ lypsykaudenvaihe $_{k=1.7}+$ tuotosluokka $_{l=1 . .8}+$ hoitokertojayht $_{m=1.5}+$ hoitovuodenaika $_{n=1 . .4}+$ ruokintatyyppi $_{o=1 . .6}+$ navettatyyppi $_{p=1 . .4}+$ makuualusta $_{q=1.4}+$ lantalatyyppi $i_{r=1 . .3}+$ karjakoko $_{s=1.5}+$ sorkkahoitaja $_{t=1.43}+\varepsilon_{i j k l m n o p q r s t u}$

Kiinteiden tekijöiden mallissa ei ollut karjatekijää eikä mallin tekijöiden yhdysvaikutuksia tutkittu. Kiinteiden tekijöiden luokittelu käy ilmi taulukosta 3. Lisäksi sorkkahoitajat (43 kpl) olivat kukin omana luokkanaan.

Sorkkasairauksiin vaikuttavien satunnaistekijöiden varianssikomponentit arvioitiin toistuvuuseläinmallilla:

$\mathrm{Y}=\mu+$ rotu + poikimakerta + lypsykaudenvaihe + hoitovuodenaika + hoitovuosi + sorkkahoitaja + karja + pysyvät ympäristötekijät + eläin $+\varepsilon$.

Mallissa kiinteinä tekijöinä olivat rotu, poikimakerta, lypsykaudenvaihe, hoitovuodenaika ja hoitovuosi. Sorkkahoitaja, karjatekijä, pysyvien ympäristötekijöiden vaikutukset, eläin (additiiviset geneettiset vaikutukset) ja jäännöstekijä olivat satunnaistekijöitä. Satunnaistekijät oletettiin normaalisti jakautuneiksi. Varianssikomponentit arvioitiin myös eläinmallilla, joka oli muuten samanlainen, mutta siitä oli jätetty pois pysyvät ympäristötekijät. Tällä mallilla varianssikomponentit arvioitiin aineistosta, jossa oli vain jokaisen eläimen ensimmäinen havainto.

Ajoissa oli mukana 41087 yksilöä, joilla oli tieto sorkkasairauksista. Sukulaisuusmatriisissa oli mukana viisi sukupolvea. Sukulaisuustiedostossa oli aineiston eläinten lisäksi 94450 yksilöä.

\section{Tulokset ja tulosten tarkastelu}

Yksi tai useampi sorkkasairaus oli 45,2 prosentilla havainnoista ja jos jokaiselta eläimeltä huomioitiin vain ensimmäinen havainto 45,8 prosentilla eläimistä (taulukko 1). Eli 54,2 prosenttia lehmistä oli terveitä.

Taulukko 1. Sorkkasairauksien yleisyydet (\%) kaikista havainnoista (n) ja eläimistä.

\begin{tabular}{lcc}
\hline Ominaisuus & $\begin{array}{c}\text { Havainnoista, \% } \\
\mathrm{n}=74410\end{array}$ & $\begin{array}{c}\text { Eläimistä, \% } \\
\mathrm{n}=41087\end{array}$ \\
\hline Vertymät anturassa & 28,2 & 30,0 \\
Valkoviivan repeämä & 10,6 & 9,0 \\
Sorkkakiertymä & 9,2 & 10,0 \\
Kantasyöpymä & 8,1 & 7,8 \\
Anturahaavauma & 3,5 & 3,7 \\
Krooninen sorkkakuume & 1,7 & 1,4 \\
Sorkkavälin ihotulehdus & 0,9 & 0,6 \\
Sorkka-alueen ihotulehdus & 0,2 & 0,1 \\
Muu sorkkasairaus & 0,8 & 0,7 \\
Sorkkasairaus & 45,2 & 45,8 \\
\hline
\end{tabular}

Kiinteiden tekijöiden vaikutusta tutkittiin sorkkasairauksiin, joiden yleisyys oli yli viisi prosenttia eli näitä sorkkasairauksia olivat vertymät anturassa, valkoviivan repeämä, kantasyöpymä ja sorkkakiertymä. Lisäksi tutkittiin kaikkia sorkkasairauksia yhtenä ominaisuutena eli sitä oliko eläin terve vai oliko eläimellä havaittu yksi tai useampi sorkkasairaus. Kiinteiden tekijöiden tilastolliset merkitsevyydet eri sorkkasairauksissa olivat hyvin samansuuntaisia LS- ja logit-malleilla (taulukko 2). 
Taulukko 2. Kiinteiden tekijöiden tilastolliset merkitsevyydet LS- ja logit-malleilla sekä LS-mallien selitysasteet.

\begin{tabular}{|c|c|c|c|c|c|c|c|c|c|c|}
\hline Tekijä & \multicolumn{10}{|c|}{ Sorkkasairaus } \\
\hline & \multicolumn{2}{|c|}{ Vertymät } & \multicolumn{2}{|c|}{ Valkoviivan r. } & \multicolumn{2}{|c|}{ Kantasyöpymä } & \multicolumn{2}{|c|}{ Sorkkakiertymä } & \multicolumn{2}{|c|}{ Sorkkasairaus } \\
\hline & LS & logit & LS & logit & LS & logit & LS & logit & LS & logit \\
\hline Rotu & $\star \star \star$ & $\star \star \star$ & $\star \star \star$ & $\star \star \star$ & & & $\star \star \star$ & $\star \star \star$ & $\star \star \star$ & $\star \star \star$ \\
\hline Poikimakerta & $\star \star \star$ & $\star \star \star$ & $\star \star \star$ & $\star \star \star$ & $\star \star \star$ & $\star \star \star$ & $\star \star \star$ & $\star \star \star$ & $\star \star \star$ & $\star \star \star$ \\
\hline Lypsykaudenv. & $\star \star \star$ & $\star \star \star \star$ & * & $\star \star$ & & & 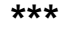 & $\star \star \star \star$ & $\star \star \star$ & $\star \star \star$ \\
\hline Tuotosluokka & $\star \star \star$ & $\star \star \star$ & & & $\star \star \star$ & $\star \star$ & $\star \star \star$ & $\star \star \star$ & $\star \star \star$ & $\star \star \star$ \\
\hline Hoitokerrat yht. & * & $\star$ & $\star \star \star$ & $\star \star$ & $\star \star \star$ & $\star \star \star$ & $\star \star \star$ & $\star \star \star$ & $\star \star \star$ & $\star \star \star$ \\
\hline Hoitovuodenaika & $\star \star \star$ & $\star \star \star$ & $\star \star \star$ & $\star \star \star$ & $\star \star \star$ & $\star \star \star *$ & $\star \star \star$ & $\star \star \star$ & $\star \star \star$ & $\star \star \star$ \\
\hline Ruokintatyyppi & & & $\star \star \star$ & $\star \star \star$ & $\star \star \star$ & $\star \star \star$ & $\star \star \star$ & $\star \star$ & $\star \star \star *$ & $\star \star \star \star$ \\
\hline Navettatyyppi & $\star \star \star$ & $\star \star \star *$ & $\star \star \star \star$ & $\star \star \star$ & $\star \star \star \star$ & $\star \star \star \star$ & $\star \star \star$ & $\star \star \star$ & $\star \star \star$ & $\star \star \star$ \\
\hline Makuualusta & $\star \star \star$ & $\star \star \star$ & $\star \star$ & $\star \star \star$ & $\star \star \star$ & $\star \star \star *$ & $\star \star \star$ & $\star \star \star$ & $\star \star \star$ & $\star \star \star$ \\
\hline Lantalatyyppi & & & * & $\star \star$ & $\star \star \star$ & $\star \star \star$ & $\star \star \star$ & $\star \star \star$ & $\star \star$ & $\star \star$ \\
\hline Karjakoko & $\star \star \star$ & $\star \star \star$ & 0 & 0 & $\star \star \star$ & $\star \star \star$ & $\star \star \star$ & $\star \star \star$ & * & 0 \\
\hline Sorkkahoitaja & $\star \star \star \star$ & $\star \star \star$ & $\star \star \star$ & $\star \star *$ & $\star \star \star$ & $\star \star \star$ & $\star \star \star$ & $\star \star \star$ & $\star \star \star$ & $\star \star \star$ \\
\hline Selitysaste, $R^{2}$ & 0,13 & & 0,08 & & 0,18 & & 0,07 & & 0,17 & \\
\hline
\end{tabular}

$* * *(\mathrm{p}<0,001), * *(\mathrm{p}<0,01), *(\mathrm{p}<0,05)$ ja $\mathrm{o}(\mathrm{p}<0,10)$

Suomenkarjan sorkkaterveys oli muita rotuja parempi, mutta suomenkarjan eläimiä oli tutkimuksessa vain vähän (taulukko 3). Ayrshire-rotuisten eläinten sorkkaterveys oli sorkkakiertymää lukuun ottamatta holstein-friisiläis -rotuisia eläimiä parempi.

Navettatyyppi oli tilastollisesti erittäin merkitsevä selittäjä jokaisen sorkkasairauden kohdalla. Erot navettatyyppien välillä olivat selkeitä ja kaikkia sorkkasairauksia esiintyi vähiten parsinavetoissa. Kantasyöpymää esiintyi yli 15 prosenttiyksikköä vähemmän parsinavetoissa kuin lämminpihatoissa ja sorkkakiertymää esiintyi parsinavetoissa kymmenisen prosenttiyksikköä enemmän kuin kummassakaan pihattotyypissä.

Kova, kuivittamaton makuualusta lisäsi sorkkasairausriskiä. Poikimakerran ja vuodenajan vaikutus oli erilainen eri sorkkasairauksilla. Sorkkasairauksia esiintyi yleisesti ottaen enemmän alkulypsykaudella (60-180 päivää poikimisesta) ja korkeatuottoisimmilla eläimillä, mutta näin ei ollut kaikkien sorkkasairauksien kohdalla. Ruokintatyypin vaikutus oli erilainen eri sorkkasairauksiin.

Myös Mansken (2002) tutkimuksen mukaan sorkkasairausriski kasvoi lehmän vanhetessa ja suurimmillaan riski sairastua oli, kun poikimisesta oli kulunut 61-150 päivää. Lisäksi korkeatuottoisilla lehmillä oli suurempi riski sairastua anturahaavaumaan. Likaiset sorkat, pihattonavetat sekä kovat lattiat olivat tiettyjen sorkkasairauksien kohdalla riskitekijöitä.

Useissa tutkimuksissa on selvitetty navetta- sekä ulkoilu- ja laidunnusympäristön vaikutusta sorkkaterveyteen. Somers ym. (2005) tutkimuksessa havaittiin, että sorkan kasvu oli nopeinta siinä vaiheessa, kun lehmät otettiin laitumelta sisälle navettaan. Aiemmassa tutkimuksessa Somers ym. (2003) havaitsivat, että olkipatjalla olleilla eläimillä oli vähiten sorkkasairauksia. Laidunnuskokeessa havaittiin, että lehmien, joita ei laidunnettu, sorkkaterveys oli huonompaa verrattuna lehmiin, jotka olivat laitumella. Myös Ral ym. (1993) tutkimuksissa sorkkaterveys oli parempi lehmillä, joita laidunnettiin verrattuna laiduntamattomaan ryhmään. 
Taulukko 3. Kiinteiden tekijöiden merkitys yleisimpien sorkkasairauksien ilmenemiseen. Poikkeamat on esitetty prosenttiyksikköinä verrattuna vertailuluokkaan.

\begin{tabular}{|c|c|c|c|c|c|c|c|}
\hline & & & $\begin{array}{l}\text { Vertymät } \\
\text { anturassa }\end{array}$ & $\begin{array}{l}\text { Valkoviivan } \\
\text { repeämä }\end{array}$ & $\begin{array}{l}\text { Kanta- } \\
\text { syöpymä }\end{array}$ & $\begin{array}{l}\text { Sorkka- } \\
\text { kiertymä }\end{array}$ & $\begin{array}{l}\text { Sorkka- } \\
\text { sairaudet }\end{array}$ \\
\hline \multicolumn{2}{|c|}{ Aineiston koko ja keskiarvot } & 74410 & 20,9 & 13,8 & 12,9 & 9,4 & 44,2 \\
\hline Tekijä & Luokka & $\mathrm{n}$ & poikkeama & poikkema & poikkeama & poikkeama & poikkeama \\
\hline \multirow[t]{3}{*}{ Rotu } & ayrshire & 52991 & 0 & 0 & 0 & 0 & 0 \\
\hline & suomenkarja & 490 & $-10,2$ & 0,2 & $-0,7$ & $-5,7$ & $-13,2$ \\
\hline & holstein-friisiläinen & 20929 & 6,8 & 4,2 & 0,0 & $-1,2$ & 7,8 \\
\hline \multirow[t]{8}{*}{ Poikimakerta } & hiehot & 323 & $-4,5$ & $-12,3$ & $-2,3$ & $-2,5$ & $-17,0$ \\
\hline & 1 & 25888 & 7,8 & $-8,1$ & $-1,5$ & 1,5 & $-0,4$ \\
\hline & 2 & 19454 & $-2,2$ & $-6,9$ & $-0,6$ & 0,9 & $-6,5$ \\
\hline & 3 & 12043 & $-1,8$ & $-3,4$ & 0,1 & 0,2 & $-3,5$ \\
\hline & 4 & 6458 & 0 & 0 & 0 & 0 & 0 \\
\hline & 5 & 3203 & 2,0 & 3,7 & 0,6 & $-1,4$ & 4,6 \\
\hline & $>5$ & 2754 & 3,2 & 6,9 & 1,0 & $-3,4$ & 8,2 \\
\hline & tieto puuttuu & 4287 & $-1,4$ & $-8,8$ & 10,8 & $-0,3$ & $-11,2$ \\
\hline \multirow[t]{7}{*}{ Lypsykaudenvaihe, pv } & $0-60$ & 12771 & $-4,3$ & $-0,5$ & 0,2 & $-1,2$ & $-5,2$ \\
\hline & $60-120$ & 12239 & 12,5 & $-0,7$ & 0,4 & $-1,0$ & 8,8 \\
\hline & $120-180$ & 11212 & 10,7 & $-0,1$ & 0,3 & 0,6 & 7,8 \\
\hline & $180-240$ & 10679 & 0 & 0 & 0 & 0 & 0 \\
\hline & $240-300$ & 10079 & $-6,8$ & 0,4 & 0,0 & $-0,4$ & $-5,3$ \\
\hline & $300-360$ & 7570 & $-11,1$ & 0,5 & $-0,3$ & $-0,8$ & $-8,6$ \\
\hline & yli 360 tai puuttuu & 9860 & $-11,8$ & 0,3 & $-0,2$ & $-1,6$ & $-9,3$ \\
\hline \multirow[t]{8}{*}{ Tuotosluokka, kg } & $<6000$ & 3503 & $-0,5$ & 0,0 & $-1,0$ & $-0,4$ & $-1,8$ \\
\hline & $6000-7000$ & 7902 & $-0,7$ & 0,1 & 0,1 & 0,1 & $-0,9$ \\
\hline & $7000-8000$ & 12969 & 0 & 0 & 0 & 0 & 0 \\
\hline & $8000-9000$ & 14280 & $-0,9$ & 0,1 & 0,3 & 0,0 & $-0,5$ \\
\hline & $9000-10000$ & 11388 & 0,0 & 0,3 & 0,6 & $-1,1$ & $-0,1$ \\
\hline & $10000-11000$ & 7036 & 1,3 & 0,1 & 0,8 & $-1,3$ & 1,2 \\
\hline & $>11000$ & 5792 & 3,8 & 0,3 & 1,1 & $-1,6$ & 3,3 \\
\hline & tieto puuttuu & 11540 & 1,2 & 0,6 & $-0,9$ & $-1,7$ & 0,0 \\
\hline \multirow[t]{5}{*}{ Hoitokerrat yhteensä } & 1 & 20778 & 0,5 & $-0,1$ & 0,0 & 0,4 & 1,5 \\
\hline & 2 & 22606 & $-0,7$ & 0,4 & $-0,4$ & 1,1 & 0,1 \\
\hline & 3 & 16857 & 0 & 0 & 0 & 0 & 0 \\
\hline & 4 & 11624 & $-0,7$ & 1,2 & $-1,3$ & $-0,2$ & $-0,9$ \\
\hline & $>4$ & 2545 & 0,3 & 2,5 & 2,6 & 2,9 & 6,4 \\
\hline \multirow[t]{4}{*}{ Hoitovuodenaika } & kevät & 25569 & $-0,8$ & $-2,8$ & $-0,2$ & $-1,0$ & $-2,8$ \\
\hline & kesä & 14867 & 0 & 0 & 0 & 0 & 0 \\
\hline & syksy & 21718 & 0,5 & 1,0 & $-1,3$ & $-1,8$ & $-1,1$ \\
\hline & talvi & 12256 & 0,9 & $-1,4$ & 3,5 & $-0,7$ & 0,1 \\
\hline \multirow[t]{5}{*}{ Ruokintatyyppi } & puolitiiviste+vilja & 30497 & 0,9 & 0,4 & $-0,1$ & 0,0 & 0,0 \\
\hline & täysrehu & 25625 & 0,6 & 1,8 & $-0,9$ & 0,5 & 1,0 \\
\hline & vilja+tiiviste & 10226 & 0 & 0 & 0 & 0 & 0 \\
\hline & seosrehu & 5676 & 0,3 & 0,0 & 3,3 & 2,7 & 4,8 \\
\hline & muu tai puuttuu & 2386 & $-1,0$ & $-0,4$ & 2,9 & 1,2 & 0,4 \\
\hline \multirow[t]{4}{*}{ Navettatyyppi } & parsi & 44322 & $-5,9$ & $-4,0$ & $-11,3$ & $-11,0$ & $-16,2$ \\
\hline & kylmäpihatto & 1332 & 0 & 0 & 0 & 0 & 0 \\
\hline & lämminpihatto & 21221 & 1,0 & 7,6 & 4,7 & $-2,1$ & 8,4 \\
\hline & tieto puuttuu & 7535 & $-3,9$ & 0,6 & $-8,6$ & $-8,5$ & $-10,8$ \\
\hline \multirow[t]{4}{*}{ Makuualusta } & kova & 9547 & 2,0 & 1,0 & 2,6 & 1,4 & 4,2 \\
\hline & matot & 55380 & 0 & 0 & 0 & 0 & 0 \\
\hline & muu & 919 & $-0,8$ & 0,2 & 0,8 & $-4,0$ & $-0,5$ \\
\hline & tieto puuttuu & 8564 & 4,1 & 2,0 & 2,9 & 0,8 & 4,2 \\
\hline \multirow[t]{3}{*}{ Lantalatyyppi } & kuiva & 23977 & 0 & 0 & 0 & 0 & 0 \\
\hline & liete & 42477 & 0,0 & 0,5 & $-1,9$ & $-1,0$ & $-1,5$ \\
\hline & tieto puuttuu & 7956 & $-2,0$ & $-1,8$ & 0,3 & 0,8 & $-0,9$ \\
\hline \multirow[t]{5}{*}{ Karjakoko } & $6-20$ & 14467 & 0,4 & 0,1 & 0,1 & $-0,2$ & 1,6 \\
\hline & $21-30$ & 23672 & $-0,3$ & $-0,4$ & 0,9 & 0,0 & 0,5 \\
\hline & $31-40$ & 16340 & 0 & 0 & 0 & 0 & 0 \\
\hline & $41-60$ & 13675 & $-1,7$ & 0,2 & 1,2 & 2,9 & 1,3 \\
\hline & $61-180$ & 6256 & $-2,5$ & $-1,0$ & 3,9 & 0,1 & 0,9 \\
\hline
\end{tabular}


Sorkkahoitajien varianssiosuudet olivat kaikissa sorkkasairauksissa periytymisasteen arvioita suurempia (taulukko 4). Valkoviivan repeämässä sorkkahoitajan varianssiosuus oli pienin, joten valkoviivan repeämän diagnosointi on todennäköisesti helpompaa kuin esimerkiksi vertymien, sorkkakiertymän tai kantasyöpymän. Valkoviivan repeämän arvioinnissa on vähemmän eroja sorkkahoitajien välillä kuin muiden sorkkasairauksien arvioinnissa. Myös karjojen varianssiosuudet olivat kaikissa sorkkasairauksissa suurempia kuin periytymisasteen arviot. Erittäin suuri karjan varianssiosuus on kantasyöpymässä, joka on tartunnallinen sorkkasairaus ja ennen kaikkea navettaolosuhteista riippuvainen sairaus. Samoin eläinkohtaisilla pysyvillä ympäristötekijöillä on suurempi osuus fenotyyppisestä varianssista kuin additiivisilla geneettisillä tekijöillä.

Taulukko 4. Sorkkasairauksien fenotyyppiset varianssikomponentit $\left(\sigma_{p}^{2}\right)$ sekä sorkkahoitajien $\left(c^{2}\right)$, karjojen $\left(c^{2}{ }_{k}\right)$ ja pysyvien ympäristötekijöiden $\left(\mathrm{c}^{2}{ }_{\mathrm{pe}}\right)$ osuudet fenotyyppisestä varianssista sekä toistumiskertoimien (r) ja periytymisasteiden $\left(\mathrm{h}^{2}\right)$ arviot.

\begin{tabular}{lcccccc}
\hline Sorkkasairaus & $s^{2}{ }_{p}$ & $c^{2}{ }_{s}$ & $c^{2}{ }_{k}$ & $c^{2}{ }_{p e}$ & $r$ & $h^{2} \pm s e$ \\
\hline Vertymät anturassa & 0,196 & 0,10 & 0,04 & 0,06 & 0,11 & $0,05 \pm 0,004$ \\
Valkoviivan repeämä & 0,094 & 0,05 & 0,06 & 0,16 & 0,19 & $0,04 \pm 0,004$ \\
Kantasyöpymä & 0,071 & 0,07 & 0,22 & 0,04 & 0,05 & $0,01 \pm 0,002$ \\
Sorkkakiertymä & 0,086 & 0,07 & 0,09 & 0,26 & 0,30 & $0,05 \pm 0,004$ \\
Sorkkasairaudet & 0,241 & 0,09 & 0,09 & 0,11 & 0,17 & $0,06 \pm 0,005$ \\
\hline
\end{tabular}

Kaikkien sorkkasairauksien periytymisasteiden arviot olivat alhaisia sekä toistuvuuseläinmallilla että eläinmallilla laskettuna. Taulukossa 4 esitetyt varianssikomponentit on laskettu toistuvuuseläinmallilla, jossa sorkkahoitaja oli satunnaistekijä. Alhaisin periytymisasteen arvio saatiin kantasyöpymälle $(0,02)$, joka on tartunnallinen sorkkasairaus ja korkein periytymisasteen arvio sorkkasairauksille yhtenä ominaisuutena $(0,06-0,07)$. Periytymisasteiden arviot ovat samaa suuruusluokkaa kuin aiemmissakin tutkimuksissa näille ominaisuuksille saadut periytymisasteiden arviot. Vertymille anturassa (Reurink \& Van Arendonk 1987), kantasyöpymälle (Huang \& Shanks 1995) ja valkoviivan repeämälle (Koenig ym. 2005) on saatu myös huomattavasti korkeampia periytymisasteen arvioita. Näissä kaikissa kolmessa tutkimuksessa aineiston koko on ollut alle 6000 eläintä. Van der Waaij ym. (2005) saivat valkoviivan repeämälle alhaisemman periytymisasteen arvion $(0,02)$, mutta vertymille anturassa vastaavasti korkeamman periytymisasteen arvion $(0,08)$ kuin tässä tutkimuksessa näille ominaisuuksille saadut periytymisasteen arviot. Kierresorkan periytymisasteen arviot ovat tutkimuksissa olleet 0,050,07 (Brotherstone ym. 1990 ja Huang \& Shanks 1995) eli hyvin samaa luokkaa kuin tässä tutkimuksessa sorkkakiertymälle saatu periytymisasteen arvio. Jalka- ja sorkkavioille yhtenä ominaisuutena saadut periytymisasteen arviot ovat vaihdelleet 0,01-0,11 (Lyons ym. 1991, Nielsen ym. 2000 ja Zwald ym. 2004).

\section{Johtopäätökset}

Tietyn ympäristötekijän vaikutus yhteen sorkkasairauteen saattaa olla täysin päinvastainen kuin johonkin toiseen sorkkasairauteen tai ympäristötekijällä ei ole lainkaan vaikutusta toiseen sorkkasairauteen. Tämän perusteella voidaan päätellä sorkkasairauksien olevan selvästi eri ominaisuuksia.

Kaikkia sorkkasairauksia esiintyi huomattavasti vähemmän parsinavetoissa, vaikka pihattoja pidetäänkin yleensä eläinystävällisempänä navettatyyppinä. Parsinavetoissa puhtaanapito on helpompaa kuin pihattonavetoissa. Lisäksi parsinavetassa on mahdollisuus eläinten yksilöllisempään hoitoon ja ruokintaan.

Ruokintatyyppi voi epäsuorasti ilmentää jonkin muun taustatekijän vaikutusta sorkkasairausalttiuteen. Väkirehumäärillä, väkirehun koostumuksella tai yleisesti ruokinnan tasapainolla on todennäköisesti suurempi vaikutus sorkkasairauksien esiintymiseen. Tuotos ja lypsykauden vaihe ilmentävät epäsuorasti väkirehumäärää, energiatasapainoa ja tuotosrasitusta. Yleisesti ottaen sorkkasairauksia esiintyi eniten alkulypsykaudella ja korkeatuottoisimmilla lehmillä, mutta näin ei ollut kaikkien sorkkasairauksien kohdalla. Vertymiä anturoissa oli selvästi eniten herumishuipun jälkeen eli vertymät näyttäisivät liittyvän lehmän energiatasapainoon ja siinä esiintyviin ongelmiin. Tähän tuotantokauden vaiheeseen liittyvät myös lehmien hedelmällisyyshäiriöt ja aineenvaihduntasairauksista muun muassa ketoosi. 
Ensikoiden huonoa sorkkaterveyttä selittää mahdollisesti ensimmäisen poikimisen aiheuttama tuotantorasitus ja ensimmäiseen poikimiseen liittyvä olosuhteiden ja ruokinnan muutos. Ensikot myös kasvavat voimakkaasti vielä ensimmäisen tuotantokautensa aikana. Sorkkakiertymää esiintyi sitä vähemmän, mitä useammin lehmä oli poikinut. Tämä selittynee sillä, että sorkkakiertymä on selvästi havaittavissa oleva vika ja siitä kärsivät eläimet karsitaan muita herkemmin.

Tämän tutkimuksen sekä aiempien tutkimusten perusteella perimän osuus 0/1-asteikolla arvioituhin sorkkasairauksiin ei ole kovin suuri. Sorkkasairauksien ennaltaehkäisyssä tulisi kiinnittää erityistä huomiota navetan olosuhteisiin, säännölliseen sorkkahoitoon ja oikeaan ruokintaan.

Jatkotutkimuksissa voitaisiin käyttää lehmän energiatasapainon mittareina sorkkahoitopäivää lähimmän koelypsypäivän maitomäärää, maidon valkuais- ja rasvapitoisuuksia sekä ureaa. Jatkossa voitaisiin myös tutkia soluluvun sekä muiden sairauksien yhteyksiä sorkkasairauksiin. Lisäksi tulisi tutkia myös rakenneominaisuuksien, lähinnä jalkarakenteen ja jalka-asentojen, yhteyksiä sorkkasairauksiin.

\section{Kirjallisuus}

Brotherstone, S., McManus, C.M. \& Hill, W.G. 1990. Estimation of genetic parameters for linear and miscellaneous type traits in Holstein-Friesian dairy cattle. Livestock Production Science 26: 177-192.

Groeneveld, E. 1997. VCE4 user's guide and reference manual. Institute of Animal Husbandry and Animal Behaviour, Federal Agricultural Research Centre, Germany. 49s.

Huang, Y.C. \& Shanks, R.D. 1995. Within herd estimates of heritabilities for six hoof characteristics and impact of dispersion of discrete severity scores on estimates. Livestock Production Science 44: 107-114.

Jankko, M. 2002. Terveillä sorkilla kestävä lehmä. Kotieläin 1: 10-11.

Koenig, S., Sharifi, A.R., Wentrot, H., Landmann, D., Eise, M. \& Simianer, H. 2005. Genetic parameters of claw and foot disorders estimated with logistic models. Journal of Dairy Science 88: 3316-3325.

Kujala, M., Schnier, C., Niemi, J. \& Soveri, T. 2004. Occurrence of hoof diseases in dairy cattle in Finland. Proceedings of 13th International Symposium and 5th Conference on Lameness in Ruminants. Saatavilla wwwmuodossa: <URL: http://www.ruminantlameness.com/end/proceedings2004.pdf> ss.45-47.

Lohenoja, S. 2005. Keskituotos ylitti 8300 kiloa - ProTuotos -seurannan tulokset 2004. Nauta 3: 6-8.

Lyons, D.T., Freeman, A.E. \& Kuck, A.L. 1991. Genetics of health traits in Holstein cattle. Journal of Dairy Science 74: 1092-1100.

Maa- ja metsätaloustuottajien keskusliitto 2004. MTK:n vuosikertomus 2004. Maa- ja metsätaloustuottajien keskusliiton julkaisuja n:o 168: 12. Saatavilla www-muodossa: <URL:

http://www.mtk.fi/mtk/julkaisut/vuosikertomukset/fi_FI/vuosikertomus2004/>.

Manske, T. 2002. Hoof lesions and lameness in Swedish dairy cattle. Doctoral thesis. Swedish University of Agricultural Sciences. [Viitattu 20.11.2004] Saatavilla www-muodossa: <URL:

http://diss-epsilon.slu.se/archive/00000081/01/Ram_Manske.pdf>

Nielsen, U.S., Aamand, G.P. \& Mark, T. 2000. National genetic evaluation of udder health and other health traits in Denmark. Interbull Bulletin 25: 143-151.

Ral, G., Ståhlhammar, E.-M. \& Philipsson. 1993. Studies on hoof disorders in Swedish dairy cattle breeds. Proceedings in $44^{\text {th }}$ EAAP meeting $44: 1-8$.

Reurink, A. \& Van Arendonk, J. 1987. Relationships of claw disorders and claw measurements with efficiency of production in dairy cattle. Proceedings at 38th Annual Meeting of the European Association for Animal Production, Lisbon, Portugal. Commission on animal genetics. Session V: Short contributed papers.

Somers, J.G.C.J., Frankena, K., Noordhuizen-Stassen, E.N. \& Metz, J.H.M. 2003. Prevalence of claw disorders in Dutch dairy cows exposed to several floor system. Journal of Dairy Science 86: 2082-2093.

Somers, J.G.C.J., Schouten, W.G.P., Frankena, K., Noordhuizen-Stassen, E.N. \& Metz, J.H.M. 2005. Development of claw traits in dairy cows kept on different floor system. Journal of Dairy Science 88: 110-120.

Vilva, V. 1998. Wsys-L-ohjelmisto. Kotieläintieteen laitos, Helsingin yliopisto, Helsinki.

Waaij, E.H. van der, Holzhauer, M., Ellen, E., Kamphuis, C. \& Jong, G. de. 2005. Genetic parameters for claw disorders in Dutch dairy cattle and correlations with conformation traits. Journal of Dairy Science 88: 3672-3678.

Zwald, N.R., Weigel, K.A., Chang, Y.M., Welper, R.D. \& Clay, J.S. 2004. Genetic selection for health traits using producer-recorded data. I. Incidence rates, heritability estimates, and sire breeding values. Journal of Dairy Science 87: 4287-4294. 